\title{
The Douro landscape heritage (NE Portugal): modernity and tradition in times of change
}

\section{Abstract}

As a consequence of its long history of more than 250 years, the Douro Demarcated Region (NE Portugal) boasts a distinct cultural landscape typified by terraces filled with the regional variety of grapevine - it is a region where famous wines are produced, in particular Port wine. Nevertheless, especially after the 1980s, the need to cover labour shortages and increase productivity led to a gradual change in the landscape, and today the traditional terraces are mixed with new types of vineyards, such as the "vinha ao alto" (vertical vines) and "vinha em patamares" (vines on terraces). Against this backdrop, and with a view to preserving the landscape in a sustainable and multifunctional way, UNESCO awarded the region the "Evolving Living Landscape, World Heritage" award. In this article we combine extensive documentary research with productive field work in order to question the relationship between the need to preserve an exceptional, cultural landscape and the need for regional sustainability in this World Heritage site.

Keywords

cultural landscape - Douro Demarcated Region - World Heritage • preservation $\cdot$ sustainability

(๑) University of Warsaw - Faculty of Geography and Regional Studies

\author{
Helena Mesquita Pina \\ Faculty of Arts and Humanities, \\ University of Porto, Portugal \\ e-mail: helenapina@netcabo.pt \\ Received: 15 February 2018 \\ Accepted: 4 June 2018
}

\section{Introduction}

Landscape, "the cultural projection of a society and of symbols that express thoughts, ideas, various emotions" (eds Nogué 2007, p.12), is a Latin word that means region: a space that can be seen at a glance from a specific spot and at a given moment, and which varies according to the viewer. It includes the distinct components of this space and can be looked at in different ways, which is why its appropriation was regulated at the "European Landscape Convention" held in Florence in 2000; according to which "landscape is a part of the territory as perceived by the population, the nature of which results from the action and interaction of natural and/or human factors." (Marques 2014, p. 30).

The landscape is diverse and versatile (Cantero 2010), and comprises structural elements such as landforms and bodies of water, different forms of spatial occupation and built structures, such as settlements and scattered farms, in addition to paths and roadways. The landscape is subject to constant appraisals, providing different perceptions that arise from the viewer's observations and reflections on its tangible and intangible qualities (Daniel 2001; Marques 2014; Pina 2013b). We, thus, become aware of the region's spatial organisation and its scenic value, as the landscape portrays natural, political, social, and economic transformations, which result in a "temporal-spatial unit in which the elements of nature and culture converge into a solid yet unstable communion" (Urquijo \& Barrera 2009, p.230).

The landscape is also constantly undergoing strategic, economic, and social interventions that are especially aimed at expanding farming, animal husbandry, forestry, industry and mining, as well as leisure and entertainment. As these do not always fit properly within environmental and social spheres, it comes as no surprise that the focus falls increasingly on mitigating the emerging problems and investing in the preservation of specific natural or cultural endogenous elements (Ingold 2000; Marques \& Castro 2005: Marques 2014; Dermendhzieva et al 2011; Lencastre 2014).

Present in all civilisations, landscapes have always been explored in literature and, in particular, in painting. In fact, pictorial representations over time show various approaches that combine realism and the mundane, the religious and the symbolic. It should be noted, though, that it was only with Vidal de La Blache that landscapes became scientifically typified as being a synthesis - as the combination of multiple components. This approach, however, was far too descriptive.

In current times, in a context where environmental and social issues are of the utmost importance due to their real impact and the need to preserve ecosystems that are perceived as being "an aggregation of all related factors" (Fariña \& Solana 2007, p.261), unique landscapes must be identified and named as cultural heritage, or even world heritage. What is at stake is their preservation, architectural elements, communities, and non-material culture (Cosgrove \& Daniels 1988; Aguiar 2000; Pina 2012a, 2013b); as well as their ecosystems, scientific and natural relevance, aesthetic-artistic dimensions, and, increasingly, experiential and sensory dimensions (Cantero 2010). This heritage is indeed the legacy we wish to leave to future generations.

The Portuguese Directorate-General for Cultural Heritage has various types of classifications for heritage, in particular: Immovable Heritage (architectural and archaeological), Movable Heritage (museum collections), and Non-material Heritage 
(traditions, music, gastronomy, etc.) (Fernandes et al 2016). Cultural landscape, therefore, corresponds to the sum of all the material and non-material assets that portray the social and cultural identity of a people, but always with the natural biotic and abiotic substrate as the backbone of human action that models and values it in order to preserve and accumulate it (Cunha 2016).

Until 1960, only historical monuments were referred to as heritage, but the concept has since then been broadened to include other elements ("Venice Charter", 1964; and "Convention Concerning the Protection of the World Cultural and Natural Heritage", 1972). In fact, under the aegis of UNESCO, and following "The Convention for the Safeguarding of Intangible Cultural Heritage" (2003), the intangible, immaterial dimensions have drawn greater attention, thus also acknowledging the communities that produced them (Pina 2012a, 2013b).

Finally, the political and economic context, in particular through investment in tourism, has transformed the landscape into a key element that needs to be explored (Cunha 2016; Pina 2013b, Pina \& Queiroz 2017). Tourism is regarded as indispensable for the improvement of quality of life, which has, consequently, led to its democratisation, and a renewed focus on the landscape. Hence, the need for a global and sustained management of this heritage, has become a priority (Pina 2014). The conservation and enhancement of this legacy does not, however, depend only on its intrinsic, objective value but also on it being socially accepted. The institutional measures taken in this regard must be scrupulously analysed so as to ensure that efficient management models are devised on which sustainable territorial development is firmly anchored (Ferreira 2012; Pina 2010, 2014). A more comprehensive and integrated management model, which is focused on the landscape at various scales, will serve to protect this heritage, particularly from the negative impacts of mass tourism.

Recognizing the specific value of a landscape means being one step closer to its conservation (Dermendhzieva et al 2011; Pina 2012a). This was the case of the Douro Demarcated Region, which is a living, evolving landscape. Phylloxera undoubtedly accelerated the transformation of the Douro landscape in the $19^{\text {th }}$ century, but almost a hundred years later, particularly from the 1980s onwards, the region suffered its most dramatic changes, that is, deepening territorial asymmetries and divides due to economic and technical development. Several questions must be asked: how can we develop and preserve this heritage? One cannot forget that this idyllic scenery has for decades attracted novelists, painters, and writers, such as Miguel Torga, Agustina Bessa Luís, and Manoel de Oliveira, and, more recently, Paulo Rocha. What impact have the political, economic and cultural interventions had on the Douro landscape? What are the consequences of the more recent transformations, namely those resulting from the planting of different types of vineyards (Queiroz et al 2010) other than the traditional ones? How can we conciliate tradition with innovation and sustainability?

This article aims to provide answers to these questions by looking into the characteristics and evolution of the Douro landscape, home to a wealth of exceptional heritage. A brief background of the region is provided, together with an explanation of some significant aspects that have impacted on the landscape and on the socioeconomic context; for example, the expansion of the vineyards, and the poor land use structure, clearly visible in the landscape. The paper concludes by highlighting some strategies, which, albeit restricted by the current context, also regulate the development policies that, in a multifunctional perspective, encourage the combination of vineyard and tourism.

\section{Methodological issues}

The importance of the various landscape factors and their impacts cannot be ignored, especially when dealing with the sustainable development of these spaces. Thus, we will address the environmental and economic factors; in particular in regard to wine growing, which is the economic mainstay of the region; and the problems affecting this sector. We will focus on the expansion of the vineyards, which will be complemented by an analysis of the most relevant land use indicators, and their underlying causes and impact on the landscape. The study is based on information from the National Statistical Institute's agricultural censuses (1989 and 2009), focusing particularly on the size of the farmsteads and the degree to which they are subdivided or parcelled. These indicators further serve to identify the most significant territorial asymmetries.

In methodological terms, the study is based on thorough documentary research and extensive fieldwork (López \& Ramirez 2013), which includes the observation and interpretation of these spaces, together with surveys of the resident population. Semi-structured interviews were also conducted with the agents responsible for spatial planning and development in the Douro region (local authorities, sector-related associations, and bodies related to viticulture, culture and tourism). The result is a diagnosis that has led to defining strategies devised to bolster this heritage (Pina 2012a; Pina \& Queiroz 2017). The region is home to a diverse range of landscapes and magnificent architectural features, a wide range of specific and unique local resources that include its distinctive history, wines of exceptional quality, and a wealth of historical-cultural and archaeological heritage (Pina 2012a; Cabral 2011; Dermendhzieva et al 2011). Other cultural attractions can also be highlighted, such as the religious feasts and processions (Pina 2010, 2012a), the traditions associated with the harvest season and farm work, thematic festivals, and regional fairs. There is an urgent need to intensify this framework, in holistic terms, with the ultimate purpose of preserving and revitalizing a region that is listed as a world heritage site by UNESCO.

The Douro Demarcated Region: a distinctive heritage Brief notes on the territorial framework

Located in a very steep and imposing valley, the DDR is characterised by a harsh yet attractive landscape, whose slopes have been carved into terraced vineyards that surround the villages and towns, and scattered farmhouses - some more stately than others - but always flanked by wine cellars and warehouses (Photos 1 and 2). This area is also characterised by centuries-old narrow, uneven paths, often along historical schist rubble walls, or olive groves that delimit the farms. Viticulture, ethnography, culture, and mysticism all come together to form this emblematic space, part of which was listed as a World Heritage site in December 2001.

Established by administrative rule and regulated in 1756 , the DDR spreads over a total of 250,000 ha, from Barqueiros and Barrô on its western border that then extends eastwards to the Spanish border (Fig. 1). This area is home to centuries-old terraced vineyards, although only 40,000 ha are taken up with continuous vineyards (Instituto Vinhos Douro Porto, 2016).

As we move across the region, we note its greatly contrasting landscape, which has led to the creation of three sub-regions with different economic, social, cultural, and landscape features: Baixo Corgo, Cima Corgo and Douro Superior (Fig. 1). The Baixo Corgo, the most humid and westernmost sub-region, but also the one with the oldest wine history, is largely made up of small familyrun farms and intensive parcelling. In the Cima Corgo, which is traditionally labelled the "heart of Port wine," the valley becomes steeper, characterised by a prevalence of schist lithosols, which makes the soil tougher to work but ideal for higher quality wines. This is where we find most of the corporate estates, which range from 100 to 700 hectares in size (Pina 2013a; Lourenço 2008). Lastly, upstream, Douro Superior, a sub-region once dedicated to 

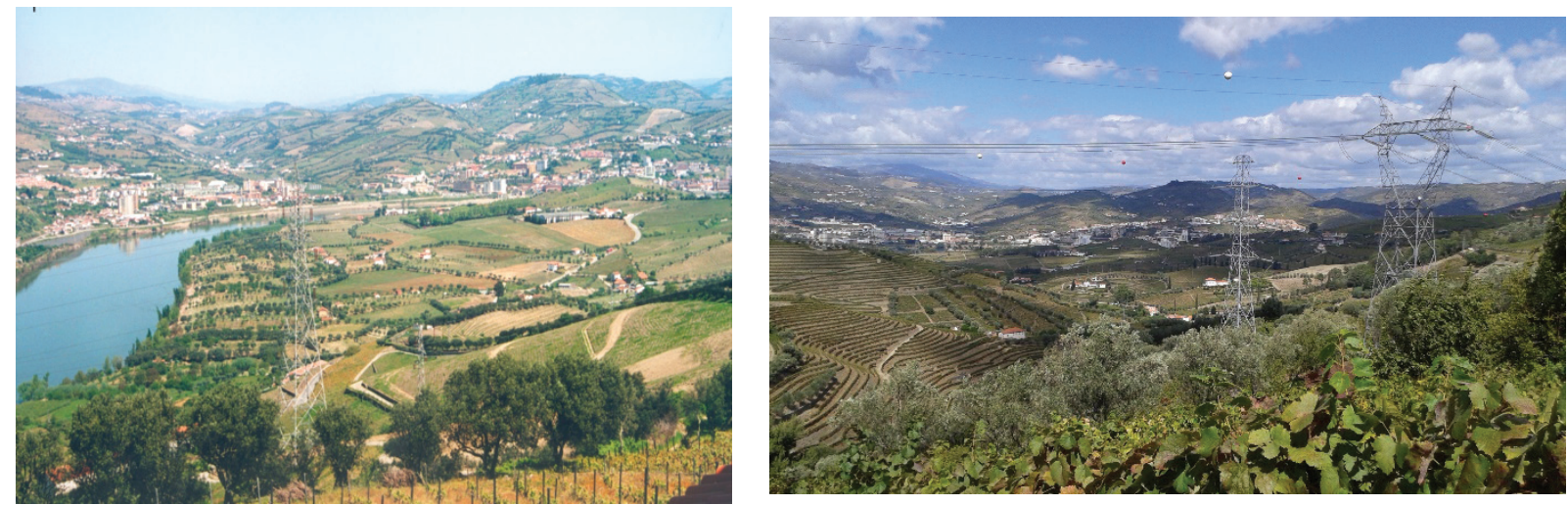

Photos 1 and 2. Two images of Baixo Corgo with farmhouses scattered throughout the landscape and olive groves surrounding the plots. (Photo by Helena Pina, 2016)

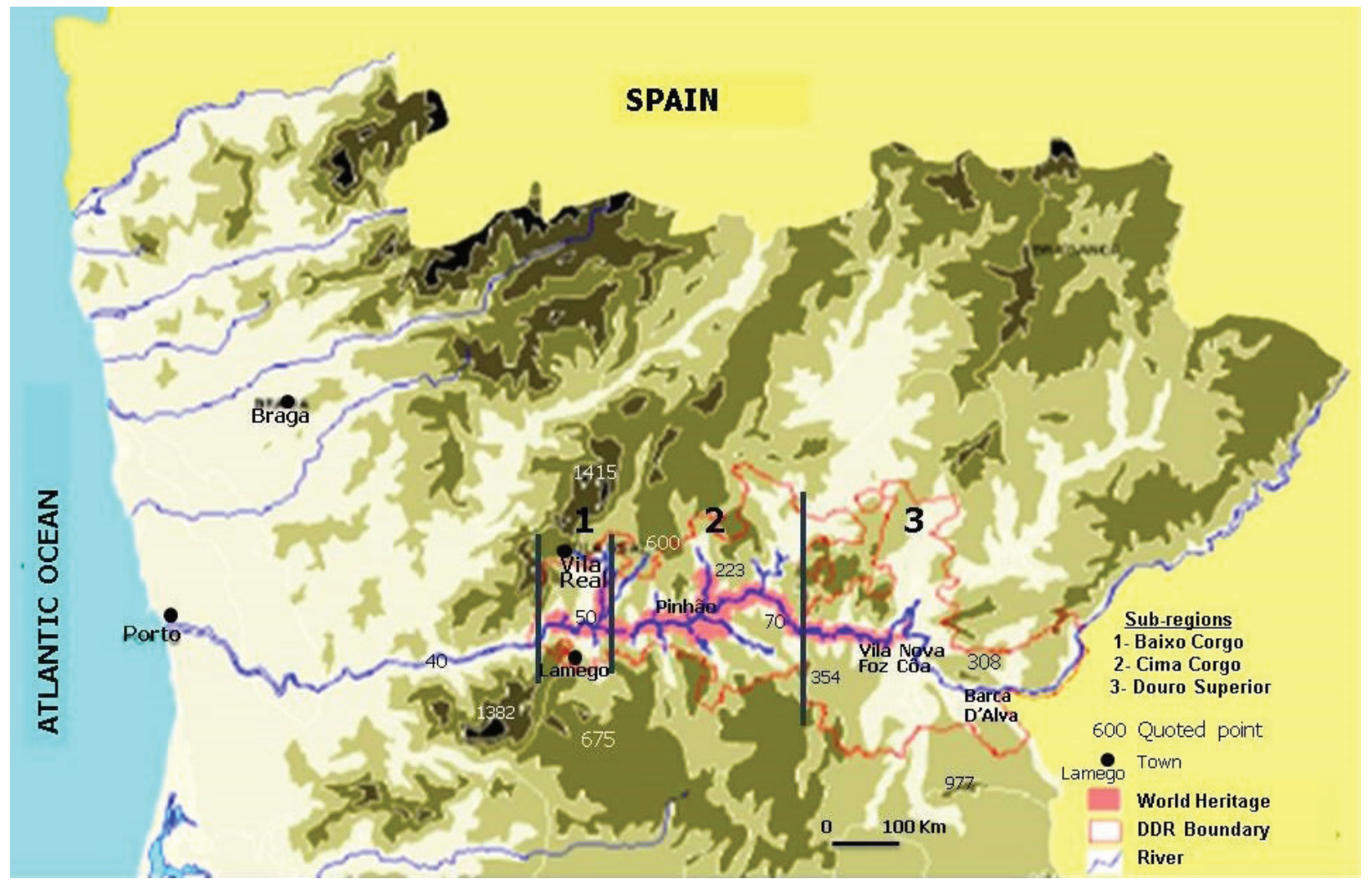

Figure 1. The Douro Demarcated Region

Source: Plano Interm. De Orden. Territ. Do Alto Douro Vinhateiro, UTAD

almond and olive groves, has since seen a significant expansion in vineyards, thus making up a totally different landscape.

This territorial mosaic is the result of many factors, among which human intervention has always been paramount. The very steep slopes found in this landscape had to be overcome through extensive terracing, an endeavour that engaged thousands of people who broke the schist rock down and created a lithosol on which to plant their specific regional grapevines (Queiroz et al 2010). These walled terraces were the only way to protect the vines and the soils from erosion.

However, regardless of the criteria on which we based our analysis, we realised that the territory lacks homogeneity.
In fact, besides the geomorphological differences, ${ }^{4}$ the region is also characterised by its climate. Surrounded by a "wall of protective reliefs" (Pina 2007) that protects it from the more humid air masses from the Atlantic Ocean ${ }^{5}$ and also from the easterly and north-easterly winds, the DDR is marked by a Mediterranean climate that is typified by some internal variations. Extremely hot summers with temperatures soaring above $35^{\circ} \mathrm{C}$ are followed by

${ }^{4}$ We recall that the schist substrate that forms the Douro region's geological formation is surrounded by granites, which are visible on the mountain ranges that delimit the winegrowing region.

${ }^{5}$ We refer here to the mountains of Marão, Alvão, and Montemuro, or even Falperra and Marofa, to mention just a few examples. 

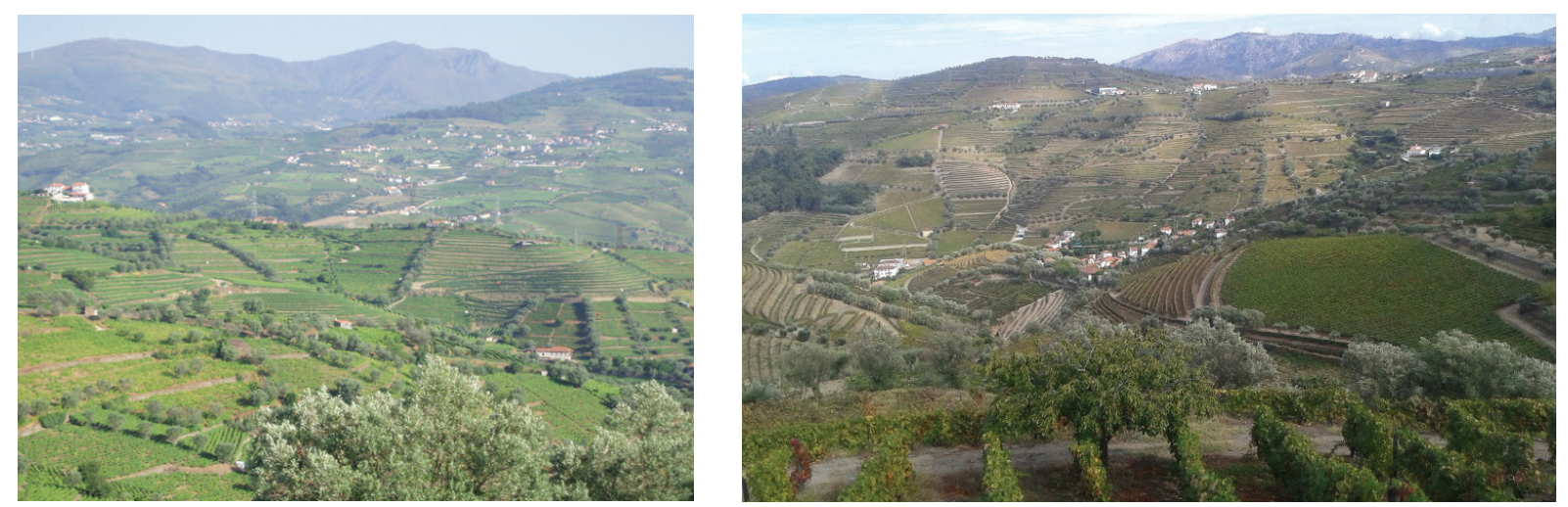

Photos 3 and 4. Two images of Baixo Corgo, one with traditional vineyards and the other with a mix of different types of terraces. (Photos by Helena Pina, 2016)

very cold temperatures (close to $0^{\circ} \mathrm{C}$ ), causing a major annual thermal variation that increases towards the sub-region on the border. The mean annual precipitation decreases from west to east, being less than $400 \mathrm{~mm}$ on the eastern border with Spain. This explains the grave water problems in Douro Superior and its impact on the winegrowing area (Rodrigues et al 2011). In Baixo Corgo, in the city of Peso da Régua, the mean annual precipitation is close to $980 \mathrm{~mm}$.

Thus, in Baixo Corgo, which is the westernmost and wettest of the sub-regions, the history of the vineyard dates from very early times (Pina 2007, 2013a), whereas in Douro Superior, since the temperatures are higher and water is scarcer, the area taken up by vineyards was smaller until the 1970s. This changed after the political revolution in 1974 when olive groves and almond trees, the most popular species until then, were replaced by vines. These territorial asymmetries and their impact on the region's organic experiences and, consequently, on the landscape, are quite evident.

The Douro vineyard landscape: a distinctive scenario

Despite its heritage and potential, the DDR has faced, for decades, multiple institutional, environmental, landscape, and economic problems, leaving its continuity on the line. ${ }^{6}$ One of the most significant problems has been caused by the problematic land use structure (Pina 2013a; Abreu 2012) given the extreme parcelling of rural properties, especially in Baixo Corgo (Photos 3 and 4). Cima Corgo is home to large farmsteads, with recent and mechanised vineyards, whose signposts, bearing the name 'quinta,' can be seen along the horizon, placed strategically on a wall or fence, in plain view (Photos 5 and 6). However, it is the small family-run wine farm measuring under 1.5 ha in size that predominate in the region.

Although farm work requires much labour, especially in the family-run farms with traditional terraces, the number of employees has gradually dropped due to the progressive mechanisation and technical development of corporate farms. With the growing scarcity of job opportunities, these employees have joined the migratory flows, especially from the second half of the $20^{\text {th }}$ century, causing severe demographic decline in the region, and leaving behind an aged population with poor technical skills (Pina 2007). The region thus faced the problem of the continuity of traditional farming. In communities with greater wine growing

${ }^{6}$ The problems are manifold, namely, the expansion of vineyards, which leads to a depreciation of wine prices, which further precariously diminishes the incomes of the already de-capitalised small wine-growers. However, it is they who actually live in the region and are the keepers of traditions and the landscape, etc. We could also add population decline and ageing, a poor internal road system, and the poor maintenance of the built heritage, among others. potential, in particular Cima Corgo and Douro Superior (Photos 5 to 8 ), despite the water shortages, the mechanised vineyards owned by the large exporting companies have increased since the 1980s, but using different types of terraces. At the time, the traditional terrace (Photo 9), whose ledges were supported by schist 'rubble' walls, was gradually replaced by "vinha ao alto" (vertical vines) or "vines on ledges" (Photo 9) (Queiroz et al 2010). While these innovations improved the quality of regional wines and offered the possibility of overcoming labour shortages, they also expanded the area taken up by the vineyards, and changed the landscape and social life (Lourenço 2008). They also often made way for water erosion, increasing the number of collapsed walls and gullies, and soil degradation. Some of these mistakes were only to be corrected in the 21 st century.

In short, productivity increased as the region became modernised (Queiroz et al 2010), but in a very dualistic manner, with transformation and the modernisation of extensive corporate wine-growing farms to ward off stagnation and overcome family tradition (Pina 2007, 2013a). Wine production increased considerably between 1989 and 2009, especially in Douro Superior and Cima Corgo. In Baixo Corgo, however, investments were made mainly in renewing the vines and grape varieties, therefore, the number of vineyards did not increase greatly. In 1989, more than $90 \%$ of the Baixo Corgo was taken up by vineyards (Fig. 2), but by 2009 that number had stagnated. In Douro Superior, at the end of the 1980 s, vineyards hardly took up $20 \%$ of the area, but by 2009 (Fig. 3) that had increased to $40 \%$ in some of the municipalities (Pina 2013a). These increases occurred in communities where the exporting companies and the wealthier families had their farms, namely in Cima Corgo.

Under these circumstances, wine surpluses increased, and had an associated impact on the budget of small family farms, which were the dominant structure in this territory (Abreu, 2012; Pina, 2013b). The severe degree of land parcelling has a crippling effect on improving land use, but still persists because these assets have sentimental value for their owners. Affection for the land; the fact that the price of Port still pays off, despite the increasing costs associated with production and the shortage of labour; and that the younger generations choose to hold two jobs so as to maintain their properties; means wine production continues to thrive and this, therefore, helps to preserve this heritage.

Large estates, in turn, expand their assets by buying neighbouring farms (Pina, 2013b) and replacing the olive and almond trees with a mechanised vineyard monoculture (Queiroz et al 2010; Pina 2012a). The farms' traditional olive grove boundaries have begun to disappear (except in Baixo Corgo), thus diminishing the historic regional biodiversity (Andresen \& Rebelo 2013). 

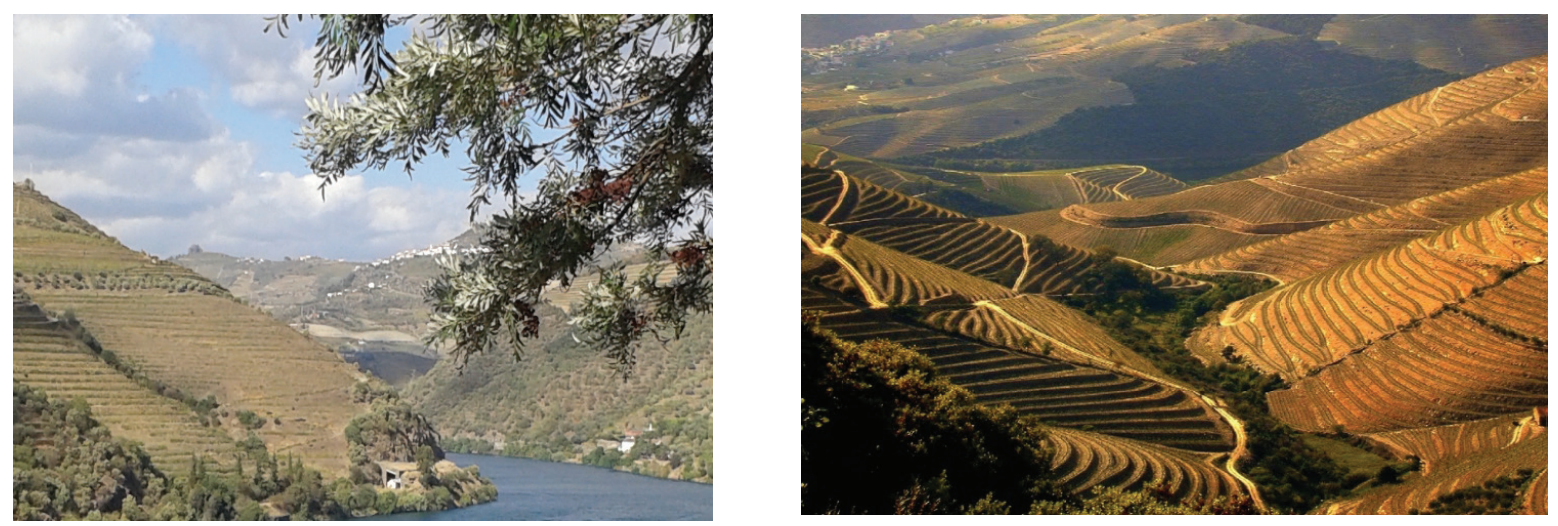

Photos 5 and 6. Cima Corgo, with the extensive mechanised business vineyards (Photos by Helena Pina, 2016)
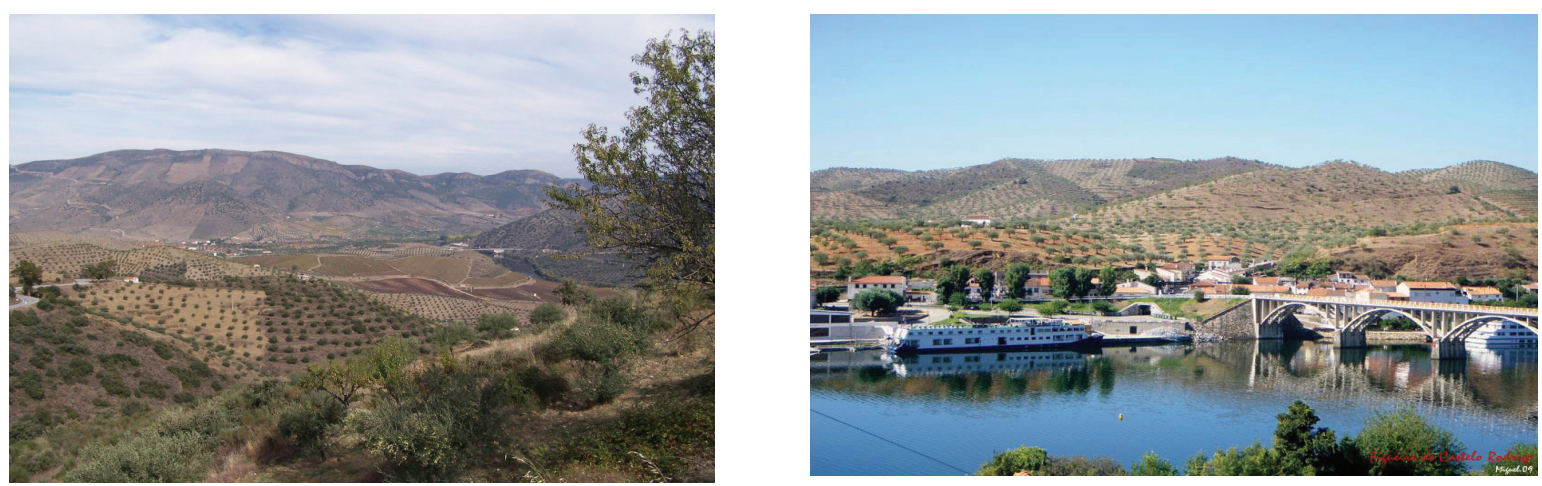

Photos 7 and 8. Douro Superior - dominion of the olive and almond tree (Photos by Helena Pina, 2016)
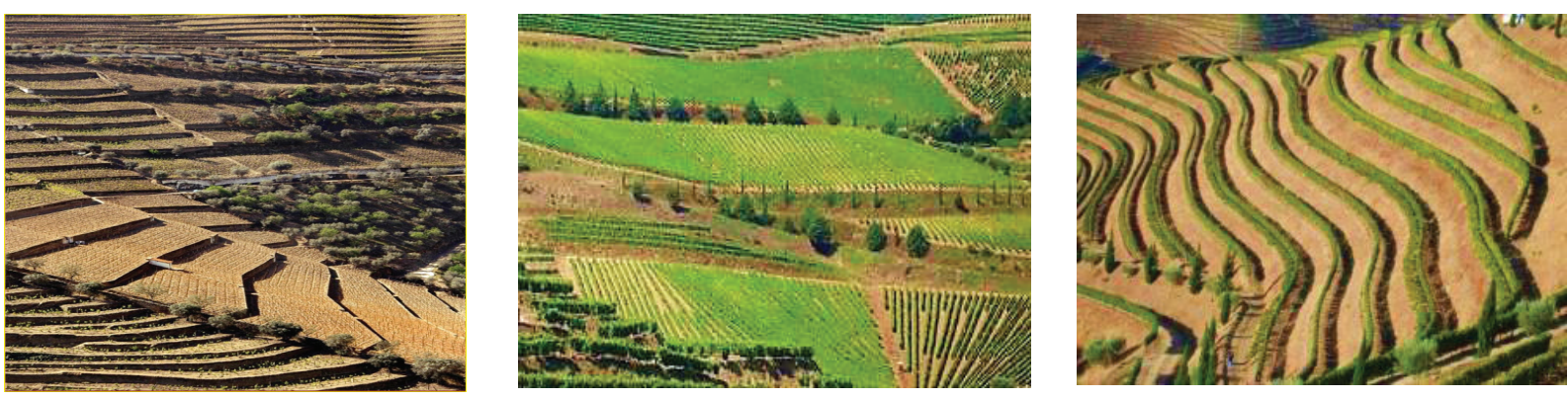

Photo 9. Vineyards with traditional terraces, at different times, flanked by "vertical vines" and "vines on ledges." (Photos J. Queiroz, 2016)

This dual scenario obviously impacts on the landscape: we find a high percentage of traditional vineyards in Baixo Corgo, albeit gradually being combined with restructured, mechanised vineyards of better quality. In Cima Corgo (Photos 5 and 6), the rise of the new type of vineyards is unquestionable, and this can be seen all the way up to Douro Superior. This is where hundreds of hectares of new mechanised vineyards have been introduced. In Douro Superior (Photos 7 and 8), the almond groves have, fortunately, been expanded with the sponsorship of the council, but this is for tourist reasons, as the purpose is to preserve the blossoming almond trees and thus the associated visiting card for tourists. The region has also taken advantage of EU funds to promote olive groves; converting the old groves and planting new ones, which have also become monoculture and mechanised. These strategies are already visible in the landscape.
Landscape preservation and regional development: some strategies

There is no doubt that the vineyard is the highlight of the landscape with many investments being made and new strategies being implemented in the DDR, including the renewal of vineyards, the use of techniques such as under-sowing to protect the soil, and investing in wines bearing the name of the wine estate. These measures are extremely important as we must never forget that the vineyard subsidises the local economic fabric (Pina 2014).

After the 1980s, and especially after 2001, an attempt to increase productivity and ensure the continuity of this heritage resulted in the following action: landscape transformation and the production and sale of wines (also olive oils) were combined with tourism, as is the case in the large farmsteads (CCDRN 2007; 


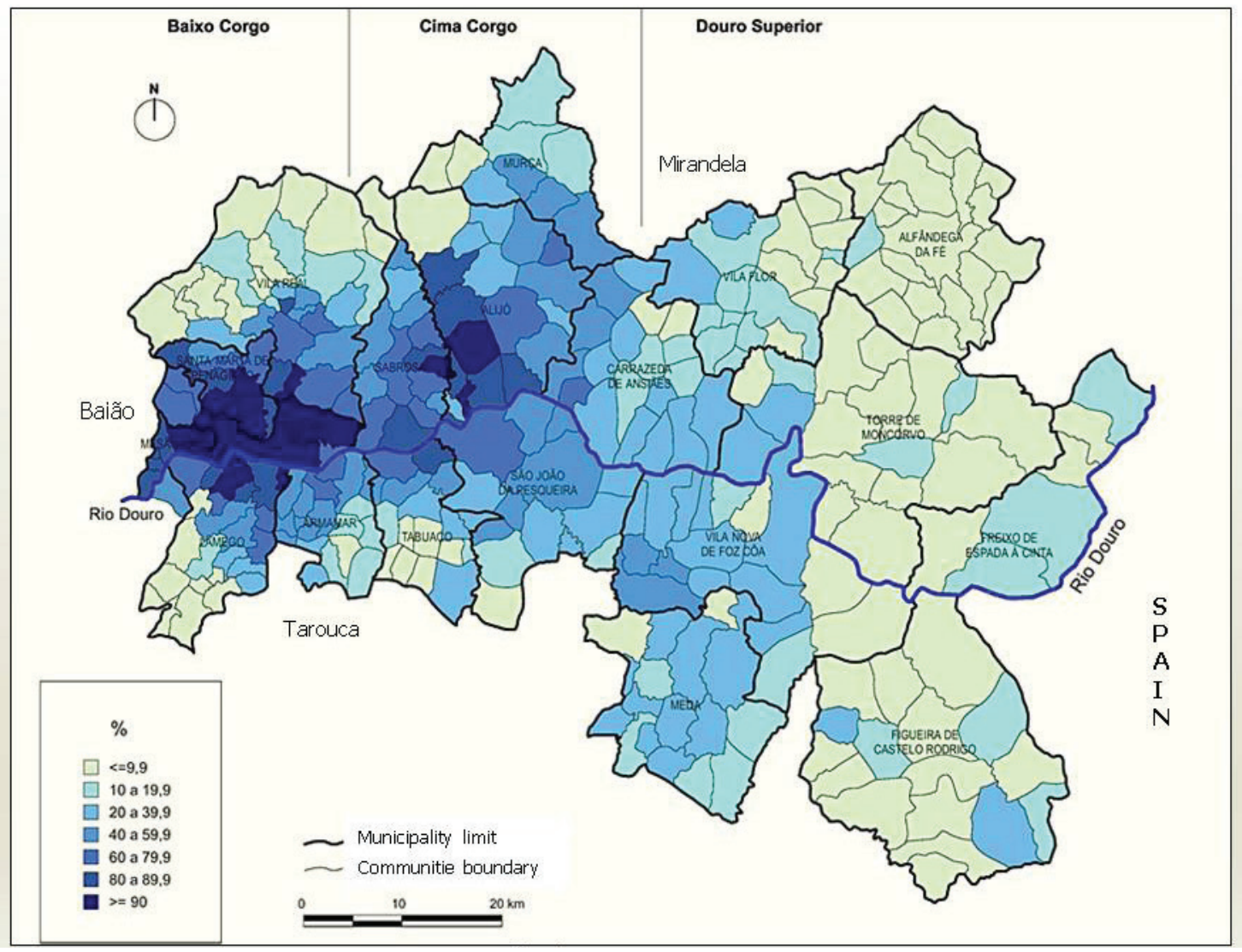

Figure 2. Proportion of area with vineyards in the SAU, ${ }^{7}$ per community, in 1989 (\%) Source: own elaboration based on Rec. Agrícola, INE 1989

Magalhães 2008; Pina 2012b, 2013b; Pina \& Queiroz 2017). This is where wine production, with the help of community funds and own capital, goes hand in hand with the sale of farm produce and with rural tourism (TER). There are many examples of this, especially in manor houses and their farms (Photos 10 and 11).

The wine farms that have joined the TER programmes, once they have renewed the vineyards, have also invested in the recovery of the built heritage where they now lodge tourists, which serves, furthermore, to disseminate the family's history, sell their products and have their guests become familiarised with the vineyard and wines. They also offer visits to wineries and cellars, wine-tasting sessions, and other entertainment activities. Thus, these landowners increase their income and recover and preserve not only their built heritage, but also their wine heritage (Pina \& Queiroz 2017). On the other hand, by signing agreements and contracts with public or private entities, or with associations, these farms also offer visitors the chance to learn about the region and its special features, even though the accommodation capacity is small and occupation is seasonal. In short, tourism, and, in particular, rural tourism (TER) is important but limited in nature as it is found in medium and large farmsteads and is a complement to wine growing.

Finally, we would like to point out that following the region's listing as a world heritage site, other more ambitious projects have emerged that are related to hospitality, including luxury hospitality. Overall, these initiatives have boosted the regional economic fabric, and have facilitated the renewal and

${ }^{7}$ SAU = USED AGRICULTURAL SURFACE - Area of the holding that includes the following: arable land (cleared and under cover of forests and forests), family gardens, permanent crops, and permanent pasture. preservation of the landscape, and the maintenance of culture, regional traditions, and handicrafts, in a milieu considered to be a "priority tourist development hub," as stated in the "Tourist Development Plan for the Douro Valley 2007-2013" (AADRN 2007; Magalhães 2008; Pina 2013b). These measures and investments will undoubtedly contribute to the preservation and enhancement of the Douro landscape and culture.

\section{Some concluding remarks}

Since the landscape is the result of human intervention, there is no doubt that man has done his share in the DDR by transforming the harsh schist substrate into a stunning landscape that reflects exceptional natural value, thus obtaining a unique and constantly changing heritage. The Douro landscapes are quite specific and unmatched, but their scenic value is sometimes threatened, and for this reason they need to be preserved, particularly in view of the quality of life of the locals as acknowledged by UNESCO and ICOMOS.

Despite all the landscape, architectural, cultural, gastronomic, and oenological potential of the region, it still faces many problems, some of which have even been heightened. We have addressed some of the problems related to wine growing, in particular the land use structure and the expansion of the vineyard. Surplus production and the adoption of new and economically more profitable vineyards has wrought changes on the nature of a landscape heritage that must be preserved. So, action had to be taken to classify the landscape, since it must be preserved - but in a sustainable and holistic manner. This is why the emphasis needs to be placed on the multifunctional potential of farms, by combining wine production with tourism. Nevertheless, 


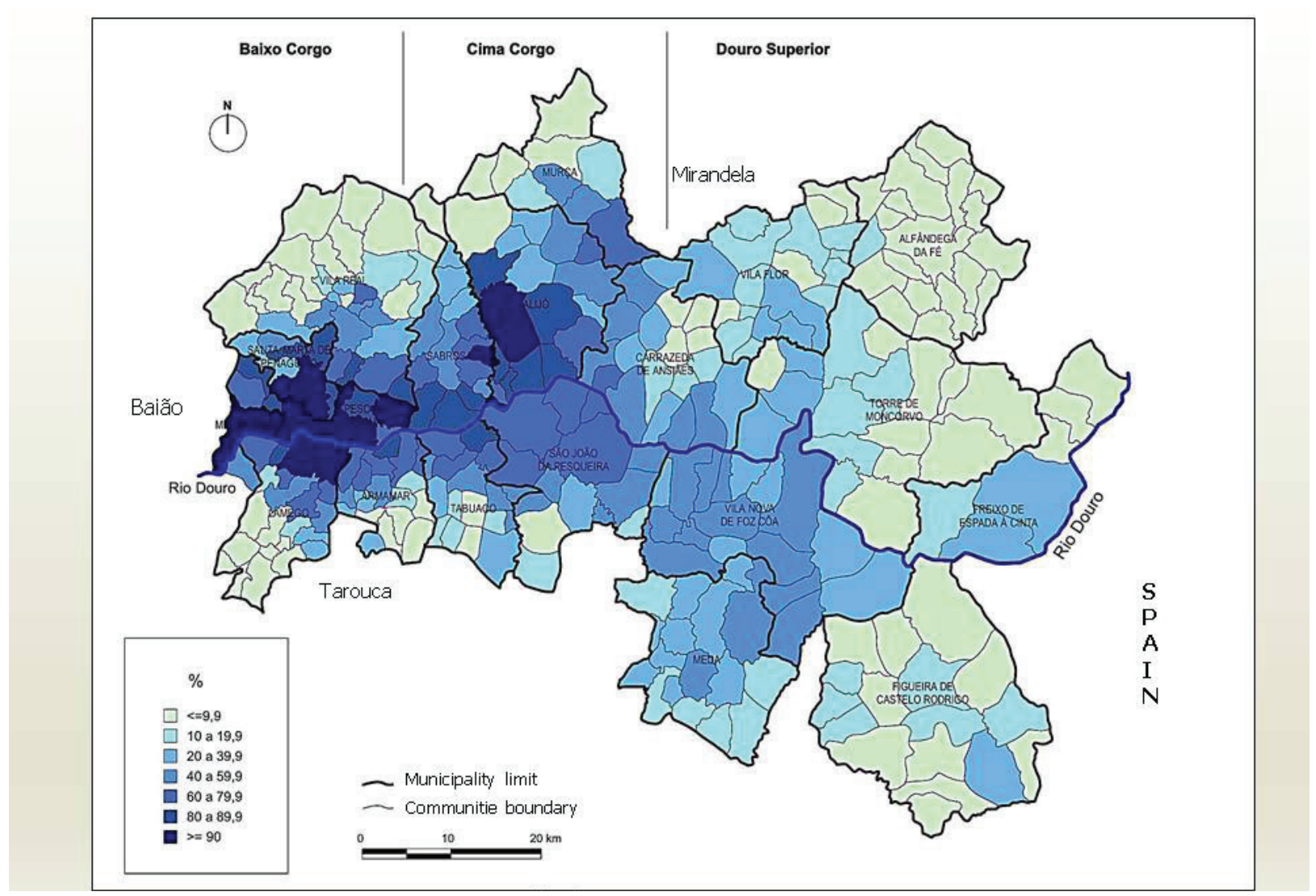

Figure 3.Proportion of area with vineyards in the SAU, ${ }^{8}$ per community, in 2009 (\%)

Source: own elaboration based on Rec. Agrícola, INE 2009
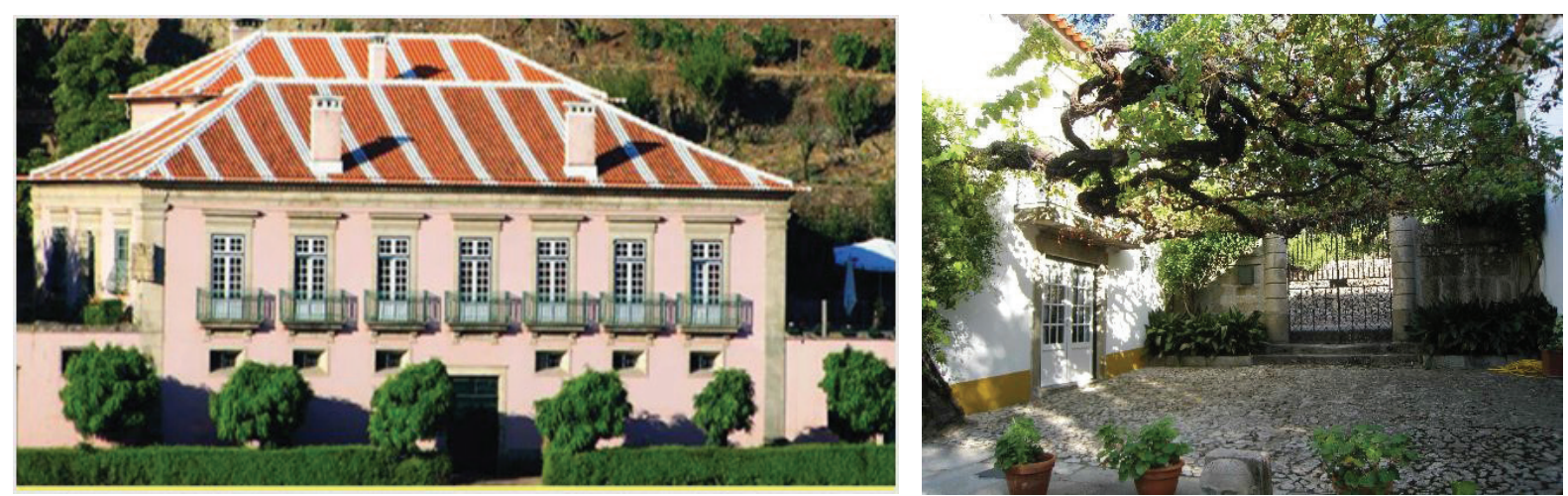

Photos 10 and 11. Two examples of manor houses adapted to tourism (Casa dos Varais and Casa da Azenha, Lamego) Source: Casa dos Varais and Casa da Azenha Archives

these guidelines are not enough; more effort must be made in terms of deepening the internal territorial complementarity with the space outside the region (Pina, 2013b). There is also a need to increase biodiversity and bolster traditional landscape elements. As noted earlier, wine growing is still the region's mainstay, but it faces many problems. Wine farmers require technical training and strategies have to be focused on mitigating the region's social, cultural, economic, and landscape problems. ${ }^{8}$

These dynamics require joint efforts and the intervention of local authorities and technical services, and, obviously, of the population in general, and wine farmers in particular. In short,

${ }^{8}$ See previous note there is a need to make better use of the region's potential and of winegrowing in particular, in a context in which development and preservation, in addition to innovation, must be combined in a balanced way. This is the only way to preserve these landscapes. The future of a region with world heritage status is at stake.

\section{Acknowledgments}

This work was financed by FEDER Funds through the Competitiveness Factors Operational Programme - COMPETE and National Funds through FCT - the Foundation for Science and Technology within CEGOT (Centre of Geographical and Land Planning Studies). 


\section{References}

Abreu, L 2012, 'Direito da Propriedade Privada e Utilização do Solo no Alto Douro Vinhateiro' ['Private Property Law and Soil Use in the Upper Douro Vineyards'], Direito Rural, vol. 34, Vida Económica Editorial S.A, Porto.

Aguiar, F 2000, 'Candidatura do Alto Douro vinhateiro a património mundial' ['Upper Douro Vineyards Application for World Heritage Status'] in Desenvolvimento e Ruralidades no Espaço Europeu [Development and Ruralities in the European Space], ed G Teixeira, APDR, Coimbra, pp. 83-90.

Andresen, T \& Rebelo, J 2013, 'Avaliação do Estado de Conservação do Bem Alto Douro Vinhateiro' ['Conservation Status Evaluation of the Upper Douro Vineyards] Paisagem Cultural Evolutiva e Viva [Cultural, Evolving and Live Countryside], - Relatório de Avaliação [Assessment Report]- vol. 1-2, Estudos de Base [Base Studies]. Porto, CIBIO UP/UTAD.

Cabral, C 2011, 'Património cultural Imaterial, Convenção da UNESCO e seus contextos' ['Intangible Cultural Heritage, UNESCO Convention and its contexts'], edições 70 [vol. 70], Lisboa Cantero, El lugar del paisage en la geografia moderna [The place of the landscape in the modern geography], Estudios geográficos, no. 269, pp. 367-393.

CCDRN 2007. Plano de Desenvolvimento Turístico do Vale do Douro [Douro Valley Tourist Development Plan], Comissão de Coordenação e Desenvolvimento Regional do Norte [Northern Regional Coordination and Development Commission], Porto.

Cosgrove, D \& Daniels, S 1988, The Iconography of Landscape, Cambridge University Press, Cambridge.

Cunha, L 2016, 'Património', in Dicionário da Geografia Aplicada, Terminologia da análise, do Planeamento e da Gestão do Território ['Heritage' in Dictionary of Applied Geography, Terminology of analysis, Planning and Management of the Territory], eds J Fernandes, L López Trigel \& E Sposito, Porto Editora, Porto, pp.364-365.

Daniel, T 2001, 'Whither scenic beauty? Visual quality assessment in the 21rst century', Landscape and urban planning, vol. 54, issues 1-4. pp. 267-281.

Dermendhzieva, S. et al. 2011, 'Danube and Douro, two rivers one destination the axis of connection or world sociocultural barriers', in Acts International Conference International dialogue and education in the Balkans and Eastern Europe, University of Verliko Tarnovo, Bulgária.

Fariña, J \& Solana, J 2007, 'El análisis del paisage'['Landscape analysis'] in La Ciudad y el Medio Ambiente [The City and the Environment ], J. Fariña Madrid, Akal.

Fernandes, J, López Trigal, L \& Sposito, E (ed.) 2016, Dicionário da Geografia Aplicada, Terminologia da análise, do planeamento e da Gestão do Território [Dictionary of Applied Geography, Terminology of analysis, Planning and Management of the Territory], Porto Editora, Porto.

Ferreira, J 2012, A Sustentabilidade do Alto Douro vinhateiro: realidade ou utopia? Contributo para a avaliação e melhoria da sustentabilidade da região [The Sustainability of the Upper Douro Vineyards: Reality or Utopia? Contribution to the assessment and improvement of the region's sustainability], FCSH, Universidade Nova de Lisboa, Lisboa.

INE 2009, Recenseamento Agrícola de Portugal de 1989 e 2009 [Agricultural Census of Portugal in 1989 and 2009], INE [National Statistics Institute], Lisboa.

Ingold, T 2000, The Perception of the Environment: essays on Livelihood, Dwelling and Skill, Routledge, USA,

Lencastre, M 2014, 'Paisagem, corpo e narrativa -como é que experiência e as palavras afectam os nossos sentidos do real?' ['Landscape, body and narrative - how do experiences and words affect our feelings of what is real?'], in Paisagem: matéria - ficção, Museu do Douro [Landscape: matter fiction, Douro Museum], eds A Magalhães \& S Guimarães, Peso da Régua, pp. 20-27.

López, L \& Ramírez, B 2013, 'Entre el arte y la ciência' ['Between art and science'], Ciudades, no. 97, pp. 8-13.

Lourenço, J, Danko, C, Fernandes, D \& Ramos, L 2008, 'Alterações dos usos solo- o caso do vale do Douro' ['Soil use alterations - the Douro Valley case'], Engenharia Civil, vol. 30, pp. 33-50.

Magalhâes, R (ed.) 2008, Plano de Desenvolvimento Turístico Vale do Douro 2005-2013 [Douro Valley Touristic Development Plan 2005 - 2013], CCDRN, Porto.

Marques, P \& Castro, L 2005, Impactes na Paisagem Identificação, Avaliação e Mitigação de Impactes Paisagísticos Negativos no Alto Douro Vinhateiro [Impacts on the Landscape - Identification, Assessment and Mitigation of Negative Landscape Impacts on the Upper Douro Vineyards], Editora da UTAD, Vila Real.

Marques, P 2014, 'Paisagem: entre o tangível e o intangível' ['Landscape: between the tangible and the intangible'] in Paisagem: matéria - ficção, Museu do Douro [Landscape: matter - fiction, Douro Museum], eds A Magalhães \& S Guimarães, Peso da Régua, pp. 28-37.

Nogué, J (ed) 2007, La construcción Social del Paisage [Social Construction of Landscapes], Biblioteca Nueva Madrid.

Pina, H 2007, O Alto Douro- um espaço contrastante em mutação [The Upper Douro - A contrasting space in mutation], vol. 1-4, Temas Portugueses [Portuguese Topics], Imprensa Nacional Casa da Moeda, Lisboa.

Pina, H 2010, 'The importance of Complementariry in the Territorial Cohesion and Sustainability of Rural Areas: The case of Cambres, a Douro Winegrowing Area, and Magueija, a Montainous Area', Revija Za Geografijo, Journal for Geography, vol. 5-2 (G10), Department of Geography, Faculty of Arts, University of Maribor (Slovenia), pp.27-42.

Pina, H 2012a, How to enhance, yet preserve, the social and cultural heritage of the Rural Douro region, including the festivities?, Espaço Aberto-PPGC, Univ. Federal Rio Janeiro, Rio de Janeiro

Pina, H 2012b, 'Quality tourism and its impacto $n$ the sustainability of rural áreas - the case of Aquapura Douro Valley (Northern Portugal)', Horizons in Geography, vol. 81/82, pp. 51-68, Telavive.

Pina, H 2013a, 'Land Use Structures in the Demarcated Douro Region: overarching trends in the last few decades' in The Sustainability of Rural Systems: global and local challenges and opportunities, eds M Cawley, A Bicalho \& L Laurens, Whitaker Institute, NUI Galway and CSRS of the International Geographical Union, Galway (Irland), pp.111-124.

Pina, H 2013b, 'The Douro Heritage: How to Conciliate Conservation, Innovation and Development?' in The Overarching Issues of The European Space - Strategies for Spatial (Re)planning based on Innovation, Sustainability and Change / Grandes Problemáticas do Espaço Europeu - Estratégias de (Re)ordenamento Territorial num Quadro de Inovação, Sustentabilidade e Mudança, ed Fundação Universidade do Porto - FLUP, Porto, pp. 183-205.

Pina, H 2014, 'The New Generation and the Strategic Development of the Alto Douro: the importance of Innovation and Entrepreneurship' in Proceeding 30 years of the Department in the University of Veliko Tarnovo, University of Veliko Tarnovo, Bulgaria, pp.125-134. 
Pina, H \& Queiroz, J 2017, 'Rural tourism and the development of the Douro Demarcated Region (NE Portugal): a strategy to promote' in Proceedings of Fifth International Congress on mountain and Steed Slope Viticulture, Conegliano, Italy, pp. 140-149.

Queiroz, J et al. 2010, 'Vine spacing in steep slope viticulture: narrow terraces, Douro Region. Viticulture en fort pente et densité de plantation: banquettes étroites, Région de Douro', CERVIM, Troisième Congrès International Viticulture de Montagne et/ou En Forte Pente, Castiglione di Sicilia, Catania, Itália.

Rodrigues, M et al 2011, 'Climatic Zoning and Vineyards Aptitude in the Douro Region (North of Portugal)' in 19th Annual Colloquium of the IGU, CSRS, NUI, Galway, Ireland

Urquijo Torres, P \& Barrera Bassols, N 2009, 'História y paisage. Explorandoun concepto geográfico monista' ['History and landscape: exploring a monist geographical concept'] Andamios, vol. 5, no. 10, pp. 227-235. 